\title{
Use of DNA barcode in the identification of catfishes (Siluriformes: Ariidae) from Malaysia
}

\author{
MOHD LUTFI ABDULLAH, SITI AZIZAH MOHD NOR, DARLINA MD. NAIM" \\ School of Biological Sciences, Universiti Sains Malaysia. 11800 Penang, Malaysia. Tel./Fax.: +60-04 653 4056, ’email: darlinamdn@usm.my
}

Manuscript received: 22 July 2017. Revision accepted: 26 August 2017.

\begin{abstract}
Abdullah ML, Nor SAM, Naim DMd. 2017. Use of DNA barcode in the identification of catfishes (Siluriformes: Ariidae) from Malaysia. Biodiversitas 18: 1358-1366. The genus Ariidae contains many valuable fish species threatened by overfishing, but knowledge on distribution and threats is still limited due to taxonomic ambiguities. The aim of this study was to apply DNA barcoding techniques to establish a resource of DNA for identification of Ariidae species in Malaysia. A 621 bp of mitochondrial cytochrome oxidase subunit I (COI) gene was utilized to resolve phylogenetic relationships and molecular taxonomy of eight presumed Malaysian Ariid species. We found the monophyly of most species was well established with a mean Kimura-2 parameter (K2P) interspecies distance of $9.6 \%$ except for two species, Arius venosus, and Nemapteryx caelata that have very low interspecies genetic distance. The BLAST result shows only two species matched the presumably eight identified fish species. Such discrepancies could arise as a result of misidentifications or errors in GenBank database input, hybridization or incomplete lineage sorting. We suggest the use of DNA barcoding is integrated into the workflow during taxonomic studies as it could significantly increase knowledge about species distributions.
\end{abstract}

Keywords: Ariidae, COI, DNA barcoding, phylogenetic, conservation

\section{INTRODUCTION}

Ariidae are distributed in marine, brackish and fresh waters of warm temperate and tropical regions of the world. Most are confined to coastal and marine habitats, but some were also found in fresh water rivers, streams, and lakes. Ariidae are locally abundant in mangrove areas, large rivers and turbid waters, as well as in fully marine waters (to $150 \mathrm{~m}$ ) and clear fresh waters (Kailola 2004; Marceniuk and Menezes 2007). There are approximately 25 species of 11 genera reportedly found in Malaysia (Yusri et al. 2010). Most ariids have high economic value due to their large size, local abundance, hardiness and flesh quality (Carpenter and Niem 1999). They are captured using a variety of gears such as demersal trawl, gill nets, and seines and are sold fresh, smoked and brined (Carpenter and Niem 1999). In Malaysia, the Department of Fisheries $(2006,2007)$ reported that approximately 11,645 tons of ariids species were harvested in 2006, but the number was increasing to 12,657 tons in 2007. From the 12,657 tons captured in $2007,7,515$ tons were from the west coast, 928 tons from the east coast and 4,214 tons from Sarawak, Sabah and the Federal Territory of Labuan. The increment of yearly ariids captured of about $9 \%$ inferred that they have a high demand value in the market.

Analogous to the increasing demands of fish products in recent years giving rise to the flow of more players into this business. This has encouraged economic deception that involves misbranding and false labelling of costly fish species with lower priced species (Rasmussen et al. 2009; Miller and Mariani 2010). Furthermore, such misidentification has also raised food safety concern such as cases of toxic puffer fish samples that mislabelled as 'headless monkfish' or other harmless products (Cohen et al. 2009). Fisheries conservation and sustainability have also been neglected to the point of commercializing overexploited species (Jacquet and Pauly 2008). There are many cases of substitution of closely related species from other countries or continent among commercialized fish due to an ambiguous nomenclature. Some species are grouped into a single name such as tuna (Lowenstein et al. 2009) while there are also singular species with multiple nomenclatures (Barbuto et al. 2010).

Indeed, understanding the taxonomic details of a species is central to the development of successful management strategies for sustainable fisheries resources (Abu Bakar and Md. Naim 2014). For centuries, taxonomic identification of fishes is mainly morphologically based. However, there are limitations to relying primarily on morphological-based characterization when attempting to identify animal species during various stages of their development or when examining fragmentary or processed remains. In other words, morphological distinction alone is inadequate for species identification or for elucidating valid phylogenetic relationships (Grewe et al. 1993; Felsenstein 2001).

Taxonomic ambiguity exists for several fish/genera including ariid family. Although the morphological characteristics have been outlined and used, however, the technique has been considered inconsistent and of limited information (Marceniuk and Menezes 2007). To illustrate, Kailola (2004) have recognized 23 valid genera of ariids which later revised by Marceniuk and Menezes (2007) who successfully recognized 26 valid genera. Afterward, recent application of molecular techniques aid in the revision of 
the ariids taxonomy. Interestingly, the study done by Betancur and Acero (2007) are incongruent with the classification suggested by both Kailola (2004) and Marceniuk and Menezes (2007). Obviously, such complexity within Ariidae requires a tool which can help to solve the taxonomic problems.

Due to the above taxonomic uncertainty, we utilize the mitochondrial DNA cytochrome oxidase subunit I (COI) gene to investigate the phylogenetic relationships among the Malaysian Ariidae using a DNA barcoding technique, which was declared as one of the increasingly important taxonomic tools for species detection (Hebert et al. 2009). The COI is one of the most conserved protein-encoding genes in the mitochondrial genome, hence, it is used to catalog animal biodiversity (Hebert et al. 2010; Ward et al. 2009). The principal aims of this study are to examine the ability of the COI gene as a DNA barcode for ariids species and to genetically identify the ariids species from Malaysia. It is anticipated that this research will provide a baseline genetic data that are required for planning the management strategy for fisheries resource in Malaysia.

\section{MATERIALS AND METHODS}

\section{Sample collection}

A total of 45 individuals that represent eight species of Ariidae namely Netuma thalassina $(\mathrm{n}=9)$, Plicofollis argyropleuron $(\mathrm{n}=5)$, Plicofollis polystaphylodon $(\mathrm{n}=5)$, Nemapteryx caelata $(\mathrm{n}=9)$, Hexanematichthys sagor $(\mathrm{n}=5)$, Arius maculatus $(\mathrm{n}=5)$, Osteogeneiosus militaris $(\mathrm{n}=5)$, and Arius venosus $(\mathrm{n}=2)$ were collected from six different locations; four in Peninsular Malaysia (PM) - (Merbok, Tanjong Dawai, Telok Bahang and Hutan Melintang) and two in East Malaysia (Sandakan and Tawau in Sabah)
(Figure 1). All species collected were identified by referring to FAO identification sheet (Fisher and Bianchi 1984; Carpenter and Niem 1999). From each specimen, approximately 5-10 g of tissues were cut and stored in 75\% ethanol. Samples were stored at room temperature prior to DNA extraction.

\section{DNA isolation and sequencing}

Total genomic DNA from tissue was extracted by using AquaGenomic Solution Protocol Kits (MultiTarget Pharmaceuticals) following manufacturer protocols with some modification of the original protocol in order to improve the yield and quality of the extracted DNA. Polymerase chain reaction (PCR) was used to amplify the target region of the cytochrome oxidase subunit I (COI) gene in the mtDNA genome of all species sampled. Each PCR amplification was performed in the total volume of $25 \mu \mathrm{L}$ of PCR mixture consisting of $18.75 \mu \mathrm{L}$ ultrapure water, 2.25 $\mu \mathrm{L} 10 \mathrm{X}$ PCR buffer, $3.0 \mu \mathrm{L} \mathrm{MgCl}_{2}, 0.25 \mu \mathrm{L}$ of each primer (FishF1 - 5'TCAACCAACCACAAAGACATTGGCAC3', FishR1 - 5'TAGACTTCTGGGTGGCCAAAGAATCA3') (Ward et al. 2009), $0.5 \mu \mathrm{L}$ of dNTP, $0.1 \mu \mathrm{L}$ of Taq polymerase, and $1.5 \mu \mathrm{L}$ of DNA template. The amplification condition consisted an initial step for $2 \mathrm{~min}$ at $95^{\circ} \mathrm{C}$ followed by 35 cycles of $0.5 \mathrm{~min}$ at $94^{\circ} \mathrm{C}, 0.5 \mathrm{~min}$ at $54^{\circ} \mathrm{C}$, and $1 \mathrm{~min}$ at $72^{\circ} \mathrm{C}$, followed by a final incubation at $72^{\circ} \mathrm{C}$ for $10 \mathrm{~min}$. The PCR products were visualized on an agarose gel and the most intense bands were selected for purification according to the Wizard ${ }^{\circledR}$ SV Gel and PCR Clean-Up System (Promega Corporation, Madison, WI, USA). Purified PCR products were then sent for sequencing using an $\mathrm{ABI} 3730$ sequencing machine provided by First Base Laboratories (Taiwan) and Center for Chemical and Biology, Universiti Sains Malaysia, Penang, Malaysia.

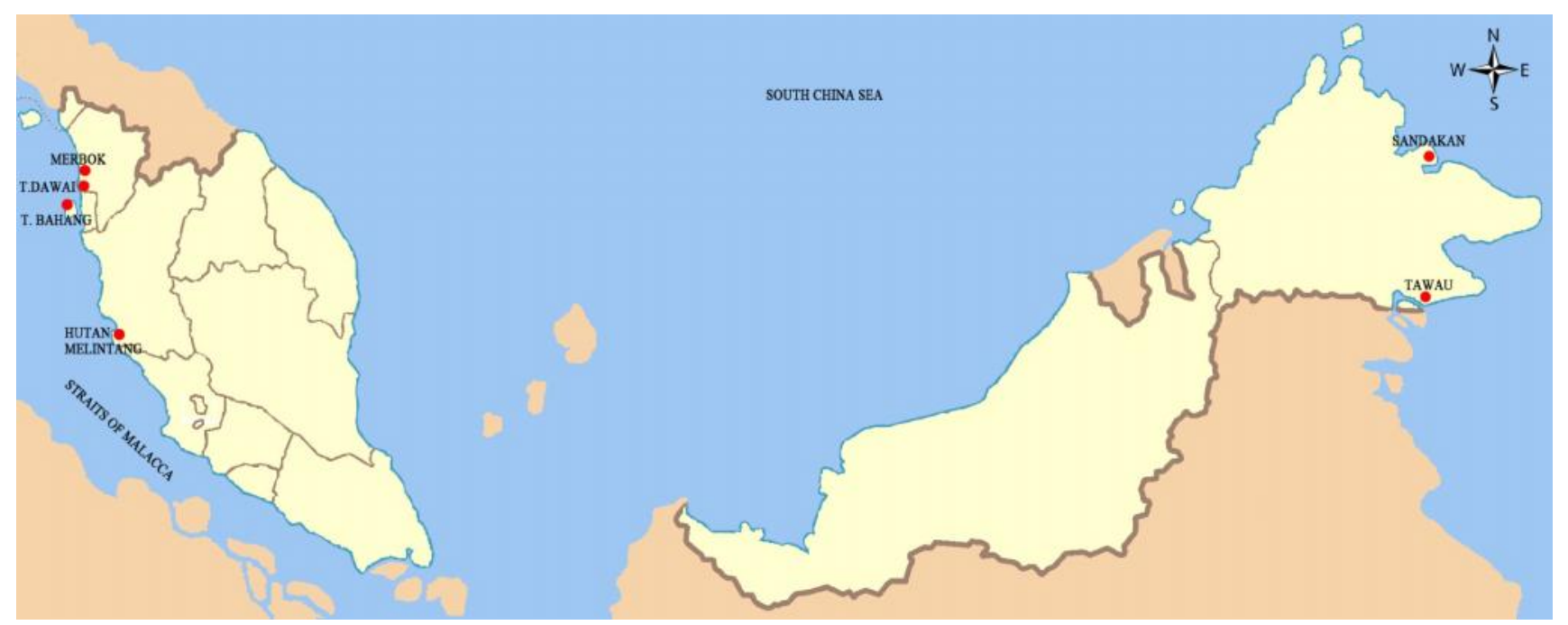

Figure 1. The location of catfishes samples collected from Malaysia 


\section{Data analysis}

Five individuals of each species were selected for phylogenetic analysis except Netuma thalassina, $N$. caelata and $A$. venosus. $N$. thalassina represented by nine individuals from two different populations; Sandakan $(\mathrm{n}=5)$ (East Malaysia) and Hutan Melintang $(\mathrm{n}=4)$ (Northern Peninsular Malaysia). N. caelata were represented by nine individuals from two different populations in Northern Peninsular Malaysia; Merbok $(\mathrm{n}=5)$ and Tanjong Dawai $(\mathrm{n}=4)$, while $A$. venosus represented by only 2 individuals. Sequences were aligned and visualized using ClustalW in MEGA ver. 5 (Tamura et al. 2011). The resulting sequences for each individual were then aligned using CLUSTAL W ver. 1.6 (Thompson et al. 1994) and were manually checked and trimmed in the BIOEDIT ver 7.0.9 sequence-editing program (Hall 1999); alignments were subsequently revised by eye in an effort to maximize positional homology. The final alignment that consisted of 621 base pairs was then imported into Basic Local Alignment Search Tool (BLAST; http://www.ncbi.nlm.nih.gov/blast) to ensure the identity of the samples. Conspecific COI sequences of three species namely $N$. thalassina (JN242655, EF609288, HQ149892, EF607327, EU014255), A. maculatus (HQ009490, FJ403390) and O. militaris (EF609566, EF609564, EF609562) that were available in GenBank of Barcode of Life Database (BOLD) were also included in the analysis and compared with the aligned sequences.

Out of 25 ariid species reported in Malaysia, only four species have their COI sequences available in GenBank. The four species with their respective sequence are as follows; (i) Arius arius (EU148551, EU148549, EU148552, EU148550, EU148548), (ii) Arius jella (FJ265865), (iii) Arius subrostratus (EU148555, EU148556, FJ624208) and (iv) Bagre marinus (GU225557, GU225558, GU225559, GU225560). With that, a total of 71 sequences were included in the analysis (Table 1). The phylogenetic relationship tree was constructed under Maximum Parsimony (MP) and Maximum Likelihood (ML) algorithm. Plotosus lineatus (EU148554) of Plotosidae was selected as an outgroup because morphologically it shows a close relationship to ariids. Genetic distances within and between species calculated based on Kimura-2 parameter (Kimura 1980). In a case for overlooked species, we employed a sequence divergence of $3.5 \%$ as a screening threshold as recommended by Hebert et al. (2004). This is a conservative threshold that approximates 10 times the average within-species COI sequence variation that is typical for marine fishes (Ward et al. 2005; Steinke et al. 2009).

\section{RESULTS AND DISCUSSION}

\section{BLAST analysis}

The BLAST result shows that only $N$. thalassina and $O$. militaris showing similarity with the species presumably identified. The remaining six species namely $P$. argyropleuron, P. polystaphylodon, N. caelata, H. sagor, A. maculatus and A. venosus did not match with species presumably identified (Table 2).

\section{Maximum Likelihood and Maximum Parsimony analysis}

Maximum likelihood (ML) and Maximum Parsimony (MP) constructed under the Kimura 2-parameter shows almost the same topology, thus only ML tree will be discussed. The tree bifurcated into two main clades. All the Ariidae species were grouped in the main clade, with the outgroup (Plotosidae) formed the basal root. On the upper part of the tree, all the sequences of $O$. militaris, including conspecific sequences retrieved from GenBank were grouped together forming their own clade with $98 \%$ support. Two sequences of $A$. maculatus obtained from GenBank (accession number: FJ403390 and HQ009490) however does not clustered together with the presumed $A$. maculatus collected in this study, but placed together with the group of Arius arius retrieved from GenBank (Figure 2). Except for A. venosus which placed in a clade of $N$. caelata, the rest of the individual ( $N$. caelata, N. thalassina, P. argyropleuron, P. polystaphylodon and H. sagor) were placed within their own group with a high support, thus forming a clear and observable species basis clade. This pattern also showed by GenBank sequences of Arius subrostratus and Bagre marinus, which also group together, forming their own subclade with $99 \%$ support respectively. However, two individual sequences retrieved from GenBank ( $N$. thalassina, accession number: JN242655 and EF607327) were not placed in their own subclade, but they were located between $A$. maculatus and N. caelata group (Figure 2).

\section{Genetic distance}

The genetic distance (Table 3) within and between species (including GenBank sequences) was calculated based on Kimura-2 parameter (K2P). Intraspecific genetic distances showed a small difference, ranged from 0.000 to 0.042 (Table 3). The genetic distances between species ranged from the lowest (0.004) between A. venosus and $N$. caelata to the highest $(0.169)$ between $O$. militaris and Bagre marinus. A slightly higher interspecific genetic distances (0.037) was also observed between A. maculatus and $A$. arius. The genetic distances between $A$. jella cannot be calculated since it represented by only one individual.

\section{Discussion}

The placement of A. venosus together with $N$. caelata clade in Maximum Likelihood (Figure 2) and the low genetic distances (0.004) (Table 3) between both species has raised a question either A. venosus and N. caelata is actually the same species, but has reported as a different species, or presumably A. venosus is actually $N$. caelata, but misidentified as A. venosus due to morphological complexity.

Accordingly, the morphology of two individual of $A$. venosus was relooked. Wongratana and Bhatia (1974) have highlights the similarities of morphological characteristic 
between $A$. venosus and $N$. caelata, which may lead to misidentification. Wongratana and Bhatia (1974) reported that both species can be differentiated by looking at their head shield and palatal teeth. $N$. caelata is described to have strongly rugose and granulated head shield. Its supraoccipital process is short, as long as broad at base, with the median keel and its hind end concave. While their teeth in jaws small and fine, those in upper jaw (premaxillary teeth) in a long and narrow band, eight to ten times longer than broad; palate teeth in one patch on each side, small and fine, front margins of patches longest and convex, separated from each other and from jaw teeth by a space somewhat less than their width (Figure 3).

Table 1. Presumptive species identification of catfishes collected samples from wild and samples obtained from GenBank

\begin{tabular}{lclll}
\hline $\begin{array}{c}\text { Presumptive species } \\
\text { identification }\end{array}$ & $\begin{array}{c}\text { No. of } \\
\text { specimen }\end{array}$ & Source & $\begin{array}{c}\text { Collection } \\
\text { site }\end{array}$ & $\begin{array}{c}\text { Accession } \\
\text { number }\end{array}$ \\
\hline N. thalassina & 5 & Wild & Sandakan & - \\
& 4 & Wild & H. Melintang & - \\
& 5 & GenBank & & JN242655 \\
& & & & EF609288 \\
& & & & HQ149892 \\
& & & & EF607327 \\
& & & & EU014255
\end{tabular}

$\begin{array}{lllll}\text { P.argyropleuron } & 5 & \text { Wild } & \text { Merbok } \\ \text { P.polystaphylodon } & 5 & \text { Wild } & \text { Tawau } & \text { - } \\ & & & & \\ \text { N. caelata } & 4 & \text { Wild } & \text { Merbok } & \text { - } \\ & 5 & \text { Wild } & \text { T. Dawai } & \text { - } \\ \text { H. sagor } & 5 & \text { Wild } & \text { H. Melintang - }\end{array}$

$\begin{array}{llll}\text { A. maculatus } & 5 & \text { Wild Merbok } & - \\ & 2 & \text { GenBank } & \text { HQ009490 } \\ & & & \text { FJ403390 } \\ \text { O. militaris } & 5 & \text { Wild Teluk } & - \\ & 5 & \text { GenBank Bahang } & \text { EF609566 } \\ & & \text { EF609564 } \\ & & \text { EF609562 }\end{array}$

$\begin{array}{lcll}\begin{array}{l}\text { A. venosus } \\ \text { Arius arius }\end{array} & 2 & \text { Wild H. Melintang - } \\ & 5 & \text { GenBank } & \text { EU148551 } \\ & & & \text { EU148549 } \\ & & & \text { EU148552 } \\ & & & \text { EU148550 } \\ & & & \text { EU148548 } \\ \text { Arius jella } & 1 & \text { GenBank } & \text { FJ265865 } \\ \text { Arius subrostratus } & 3 & \text { GenBank } & \text { EU148555 } \\ & & & \text { EU148556 } \\ \text { Bagre marinus } & 4 & \text { GenBank } & \text { FJ624208 } \\ & & & \text { GU225557 } \\ & & & \text { GU225558 } \\ \text { Plotosus lineatus } & 1 & \text { GenBank } & \text { GU225560 } \\ & & \text { GenBank } & \text { EU148554 } \\ & & & \end{array}$

On the other hand, as recorded by Wongratana and Bhatia (1974), A. venosus is described to have head shield almost smooth; median fontanelle narrow and short, reaching to median keel of supra-occipital process, which is slightly longer than broad, its side borders straight and slightly convergent. While their premaxillary tooth-band rather broad and slightly arched, four to five times longer than broad; teeth on palate fine, only one large subtriangular group on each side, greatest length of each group about equal to curved front base, outer edge concave, the inner convex; both groups separated from each other and from jaw teeth by a space about $1 / 3$ the breadth of jaw band (Figure 3).

However, our observation cannot clearly distinguish between their head shield (Figure 4). While, the observation on the palatal teeth has caused our decision to fall in the FAO guide described by Wongratana and Bhatia (1974) (Figure 5).

Table 2. The top three BLAST result of Malaysian ariids with respective score and maximum identity

\begin{tabular}{|c|c|c|c|c|c|}
\hline $\begin{array}{c}\text { Presumably } \\
\text { identified } \\
\text { species }\end{array}$ & $\begin{array}{c}\text { Top three } \\
\text { BLAST result }\end{array}$ & $\begin{array}{l}\text { Max } \\
\text { score }\end{array}$ & $\begin{array}{l}\text { Query } \\
\text { coverage }\end{array}$ & $\begin{array}{c}\mathbf{E} \\
\text { value }\end{array}$ & $\begin{array}{c}\text { Max } \\
\text { identity }\end{array}$ \\
\hline \multirow[t]{3}{*}{ N. thalassina } & N. thalassina & 1177 & $100 \%$ & 0.0 & $99 \%$ \\
\hline & N. thalassina & 1177 & $100 \%$ & 0.0 & $99 \%$ \\
\hline & N. thalassina & 1171 & $100 \%$ & 0.0 & $99 \%$ \\
\hline \multirow[t]{3}{*}{ O. militaris } & O. militaris & 1171 & $100 \%$ & 0.0 & $99 \%$ \\
\hline & O. militaris & 1171 & $100 \%$ & 0.0 & $99 \%$ \\
\hline & N. thalassina & 906 & $100 \%$ & 0.0 & $92 \%$ \\
\hline \multirow[t]{3}{*}{ P.argyropleuron } & N. thalassina & 910 & $99 \%$ & 0.0 & $92 \%$ \\
\hline & N. thalassina & 910 & $99 \%$ & 0.0 & $92 \%$ \\
\hline & N. graeffei & 910 & $99 \%$ & 0.0 & $92 \%$ \\
\hline \multicolumn{2}{|c|}{ P.polystaphylodon N. thalassina } & 933 & $99 \%$ & 0.0 & $93 \%$ \\
\hline \multicolumn{2}{|c|}{ N. thalassina } & 933 & $99 \%$ & 0.0 & $93 \%$ \\
\hline & N. thalassina & 921 & $99 \%$ & 0.0 & $92 \%$ \\
\hline \multirow{3}{*}{ N. caelata } & A. manillensis & 998 & $100 \%$ & 0.0 & $95 \%$ \\
\hline & A. manillensis & 998 & $100 \%$ & 0.0 & $95 \%$ \\
\hline & A. manillensis & 998 & $100 \%$ & 0.0 & $95 \%$ \\
\hline \multirow{3}{*}{ H. sagor } & N. thalassina & 846 & $99 \%$ & 0.0 & $90 \%$ \\
\hline & N. thalassina & 846 & $99 \%$ & 0.0 & $90 \%$ \\
\hline & N. thalassina & 840 & $99 \%$ & 0.0 & $90 \%$ \\
\hline \multirow[t]{3}{*}{ A. maculatus } & N. thalassina & 1010 & $100 \%$ & 0.0 & $95 \%$ \\
\hline & N. thalassina & 1010 & $100 \%$ & 0.0 & $95 \%$ \\
\hline & N. thalassina & 1004 & $100 \%$ & 0.0 & $95 \%$ \\
\hline \multirow[t]{3}{*}{ A. venosus } & A. manillensis & 992 & $100 \%$ & 0.0 & $94 \%$ \\
\hline & A. manillensis & 992 & $100 \%$ & 0.0 & $94 \%$ \\
\hline & A. manillensis & 992 & $100 \%$ & 0.0 & $94 \%$ \\
\hline
\end{tabular}

Note: $N$. graeffei $=$ Neoarius graeffei 


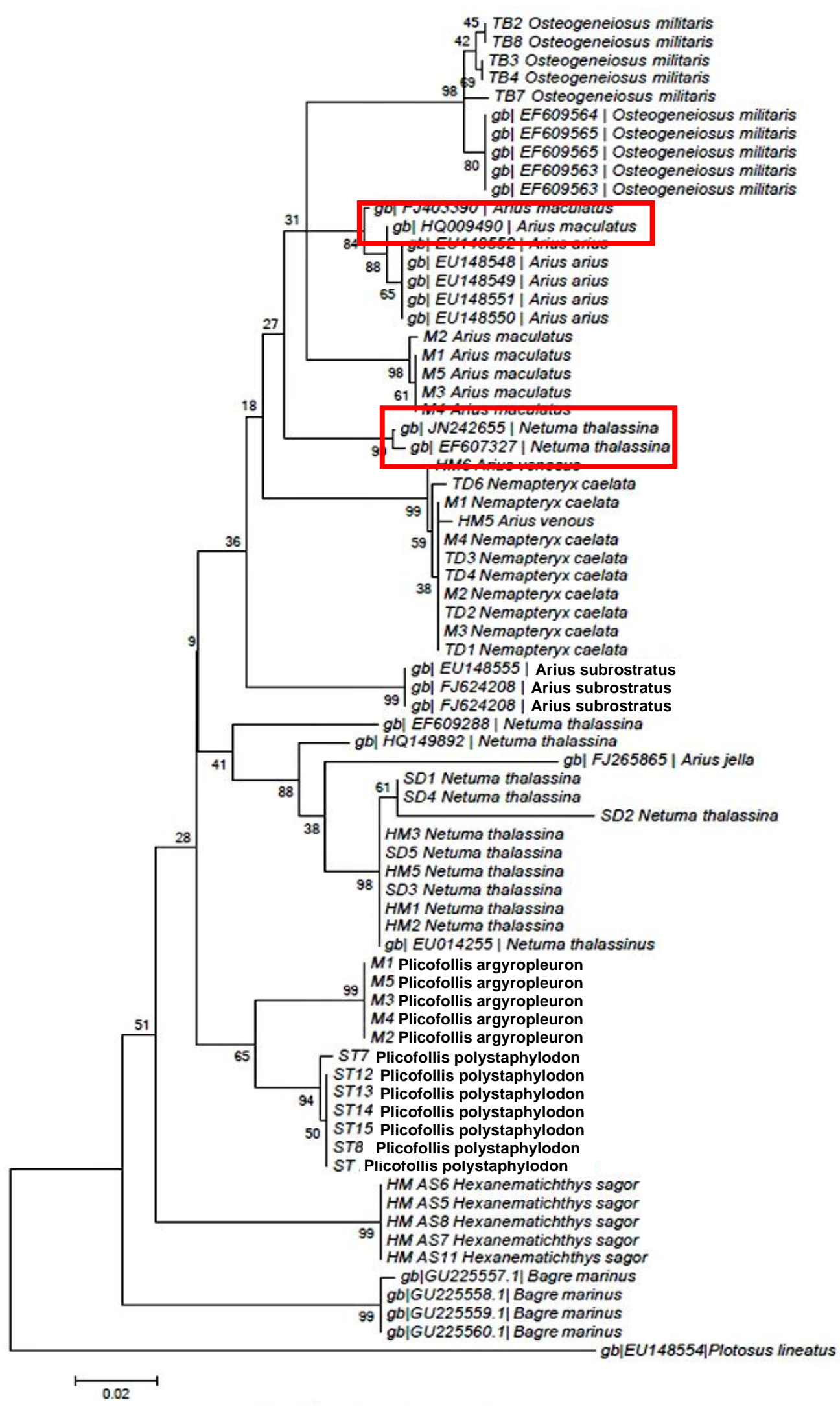

Figure 2. Maximum Likelihood (ML) tree of Ariidae from Malaysia and conspecific sequences retrieved from GenBank for COI. $\mathrm{M}=$ Merbok $\mathrm{TD}=$ Tanjong Dawai $\mathrm{HM}=$ Hutan Melintang $\mathrm{SD}=$ Sandakan $\mathrm{ST}=$ Tawau $\mathrm{gb}=\mathrm{GenBank}$. Four sequences in the box show the Netuma thalassina (accession number: JN242655, EF607327) and Arius maculatus (accession number: FJ4033390, HQ009490) retrieved from GenBank that were placed out from their group. 
Table 3. Estimation of evolutionary divergence over sequence pairs between groups within Malaysian Ariidae. The asterisk (*) shows a presumably Arius venosus. Bold indicates the high intraspecific genetic distances within $N$. thalassina.

\begin{tabular}{|c|c|c|c|c|c|c|c|c|c|c|c|c|}
\hline & $\begin{array}{c}1 \\
n=10\end{array}$ & $\underset{n=5}{2}$ & $\begin{array}{c}3 \\
n=7\end{array}$ & $\begin{array}{c}4 \\
n=9\end{array}$ & $\begin{array}{c}5 \\
n=2\end{array}$ & $\begin{array}{c}6 \\
n=3\end{array}$ & $\begin{array}{c}7 \\
n=15\end{array}$ & $\begin{array}{c}8 \\
n=5\end{array}$ & $\begin{array}{c}9 \\
n=5\end{array}$ & $\begin{array}{c}10 \\
n=5\end{array}$ & $\begin{array}{c}11 \\
n=1\end{array}$ & $\begin{array}{c}12 \\
n=4\end{array}$ \\
\hline O. militaris & 0.007 & & & & & & & & & & & \\
\hline A. arius & 0.068 & 0.000 & & & & & & & & & & \\
\hline A. maculatus & 0.068 & 0.037 & 0.021 & & & & & & & & & \\
\hline N. caelata & 0.105 & 0.072 & 0.073 & 0.001 & & & & & & & & \\
\hline A. venosus* & 0.109 & 0.076 & 0.077 & 0.004 & 0.007 & & & & & & & \\
\hline A. subrostratus & 0.099 & 0.076 & 0.076 & 0.089 & 0.088 & 0.000 & & & & & & \\
\hline N. thalassina & 0.109 & 0.094 & 0.092 & 0.110 & 0.109 & 0.114 & 0.042 & & & & & \\
\hline P. argyropleuron & 0.114 & 0.088 & 0.097 & 0.109 & 0.110 & 0.089 & 0.093 & 0.000 & & & & \\
\hline P. polystaphylodon & 0.096 & 0.087 & 0.089 & 0.092 & 0.092 & 0.079 & 0.086 & 0.045 & 0.001 & & & \\
\hline H. sagor & 0.144 & 0.118 & 0.131 & 0.123 & 0.122 & 0.105 & 0.113 & 0.101 & 0.105 & 0.000 & & \\
\hline A. jella & 0.155 & 0.123 & 0.124 & 0.146 & 0.145 & 0.150 & 0.081 & 0.132 & 0.123 & 0.158 & $\mathrm{n} / \mathrm{c}$ & \\
\hline B. marinus & 0.169 & 0.141 & 0.143 & 0.142 & 0.137 & 0.132 & 0.128 & 0.127 & 0.115 & 0.130 & 0.159 & 0.002 \\
\hline
\end{tabular}

Table 4. Estimates of evolutionary divergence over sequence pairs between groups of Malaysian ariids species. Bold indicates the intraspecific genetic distance when two GenBank's N. thalassina sequences (accession number: JN242655, EF607327) excluded.

\begin{tabular}{|c|c|c|c|c|c|c|c|c|c|c|c|c|}
\hline & $\begin{array}{c}1 \\
n=10\end{array}$ & $\begin{array}{c}2 \\
n=5\end{array}$ & $\begin{array}{c}3 \\
n=7\end{array}$ & $\begin{array}{c}4 \\
n=9\end{array}$ & $\begin{array}{c}5 \\
n=2\end{array}$ & $\begin{array}{c}6 \\
n=3\end{array}$ & $\begin{array}{c}7 \\
n=15\end{array}$ & $\begin{array}{c}8 \\
n=5\end{array}$ & $\begin{array}{c}9 \\
n=5\end{array}$ & $\begin{array}{c}10 \\
n=5\end{array}$ & $\begin{array}{c}11 \\
n=1\end{array}$ & $\begin{array}{c}12 \\
n=4\end{array}$ \\
\hline O. militaris & 0.007 & & & & & & & & & & & \\
\hline A. arius & 0.068 & 0.000 & & & & & & & & & & \\
\hline A. maculatus & 0.068 & 0.037 & 0.021 & & & & & & & & & \\
\hline N. caelata & 0.105 & 0.072 & 0.073 & 0.001 & & & & & & & & \\
\hline A. venosus* & 0.109 & 0.076 & 0.077 & 0.004 & 0.007 & & & & & & & \\
\hline A. subrostratus & 0.099 & 0.076 & 0.076 & 0.089 & 0.088 & 0.000 & & & & & & \\
\hline N. thalassina & 0.109 & 0.094 & 0.092 & 0.110 & 0.109 & 0.114 & 0.026 & & & & & \\
\hline P. argyropleuron & 0.114 & 0.088 & 0.097 & 0.109 & 0.110 & 0.089 & 0.093 & 0.000 & & & & \\
\hline P. polystaphylodon & 0.096 & 0.087 & 0.089 & 0.092 & 0.092 & 0.079 & 0.086 & 0.045 & 0.001 & & & \\
\hline H. sagor & 0.144 & 0.118 & 0.131 & 0.123 & 0.122 & 0.105 & 0.113 & 0.101 & 0.105 & 0.000 & & \\
\hline A. jella & 0.155 & 0.123 & 0.124 & 0.146 & 0.145 & 0.150 & 0.081 & 0.132 & 0.123 & 0.158 & $\mathrm{n} / \mathrm{c}$ & \\
\hline B. marinus & 0.169 & 0.141 & 0.143 & 0.142 & 0.137 & 0.132 & 0.128 & 0.127 & 0.115 & 0.130 & 0.159 & 0.002 \\
\hline
\end{tabular}

Note: *presumably Arius venosus

The BLAST result of both $N$. caelata and A. venosus also do not contribute any sign to solve this problem. BLAST analysis of both species shows similarity to the Philippines ariid Arius manillensis, with the maximum identity of $95 \%$ and $94 \%$ (Table 2). A. manillensis is first reported by Valenciennes (1840) in brackish and fresh water of Philippine. This species is described to have palatal teeth in two ovate patches, placed far forward which was clearly distinguishable with $A$. venosus and $A$. caelata (Carpenter and Niem 1999). For clarification, we decided to expand our Maximum Likelihood analysis and included five sequences of $A$. manillensis retrieved from GenBank. Interestingly, we found that A. manillensis is clearly distinguishable different species (Figure 6) and that solves the confusion raised by BLAST result (Table 2). However, it does not solve our doubt on do we misidentified $N$. caelata as A. venous, or A. venous and $N$. caelata is maybe the same species but reported as a different species: cryptic/synonymous.
Since our sample size of A. venosus in this study is very low (two individuals only) it does not give a strong support to conclude that $N$. caelata and A. venosus are the same species, but reported as different species (misidentified species). Thus, it leads to the decision that we were confused by the complexity of morphological characteristic of both species which lead us to misidentification. However, the decision is not final. Further study with large sample size of A. venosus will give a clearer picture of its status.

The high intraspecific genetic distance of $N$. thallasina (Table 3 ) is due to the sequences analyzed were obtained from many sources. As in Maximum Likelihood (Figure 2) tree, two sequences of $N$. thallasina retrieved from GenBank (accession number: JN242655 and EF607327) were placed out of other $N$. thallasina clade and eventually show more close relation to A. maculatus. With that, we hypothesized that the higher intraspecific genetic distances of $N$. thallasina is contributed by diversity of the two 
sequences included in the analysis. To clarify this hypothesis, we expand our genetic distance analysis without those two sequences (accession number: JN242655, EF607327). The analysis was based on Kimura 2-parameter model with 71 nucleotide sequences involved. As expected, the genetic distances within $N$. thalassina were reduced to 0.026 when both sequences, JN242655 and EF607327 were excluded (Table 4). This has proved our hypothesis that the higher diversity within $N$. thalassina was contributed by the diversity of sequences obtained from GenBank. Since all the GenBank's N. thalassina analyzed in this current study were originated from wide range of country (JN242655, South China Sea; EF609288, Australia; EF607327, China; HQ149892, Iran; EU014255 India), lack of consistency between different country during species identification could lead to unexpected figure in analysis.

Arius arius and A. maculatus have shown very close interspecific relationship by having a fairly low genetic distance (0.037) (Table 3). Both species also formed sister clade in Maximum Likelihood and Maximum Parsimony analysis. The close relationship between these two species is probably contributed by their similarity in morphological characteristics. Both species could be found in estuaries and inshore waters (Fisher and Bianchi 1984; Carpenter and Niem 1999). Arius arius is described to have teeth on palate in two oval-elliptical patches, one on each side, placed well forward in palate, and usually parallel to each other. While A. maculatus is described to have teeth on palate in two oval patches, one on each side placed well back in palate, with their long axes tend to converge posteriorly. Other shared morphological characteristics between both species are their coloration. Both species are bluish brown above and white below, fins yellow, dorsal, caudal and pectoral fins with dark margins, and adipose fins with large black spot. Carpenter and Niem (1999) have also highlighted the misidentification between both species.

This study provides a good support for the taxonomic status of Malaysian Ariidae, which previously studied based on morphological characteristic. On the other hand, this study also shows that DNA barcode is very effective in detection of misidentification caused by traditional identification method. Additionally, the low intraspecific genetic distances and high interspecific genetic distances between species yielded based on cytochrome oxidase subunit I proved that DNA barcoding can be utilized as a useful tool in facilitating the molecular phylogenetic and population genetic field. Thus the work on establishing DNA barcode for all species of Ariidae must be continued.

\section{ACKNOWLEDGEMENTS}

We would like to thank all staff of the Molecular Ecology and Population Genetics Laboratory, School of Biological Sciences, Universiti Sains Malaysia. This research was supported by the Universiti Sains Malaysia Short Term Grant \#304/PBIO/6312027 and the Research University Grant \#1001/PBIO/815087.
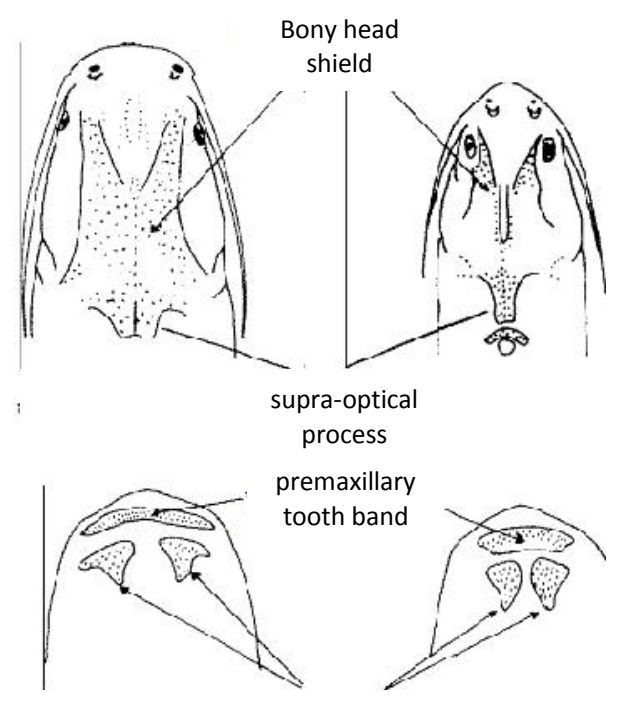

palatine tooth patches

(roof of mouth)

Figure 3. Differentiation between head shield and palatal teeth of both Nemapteryx caelata (left) and Arius venosus (right). Image modified from Wongratana and Bhatia (1974)

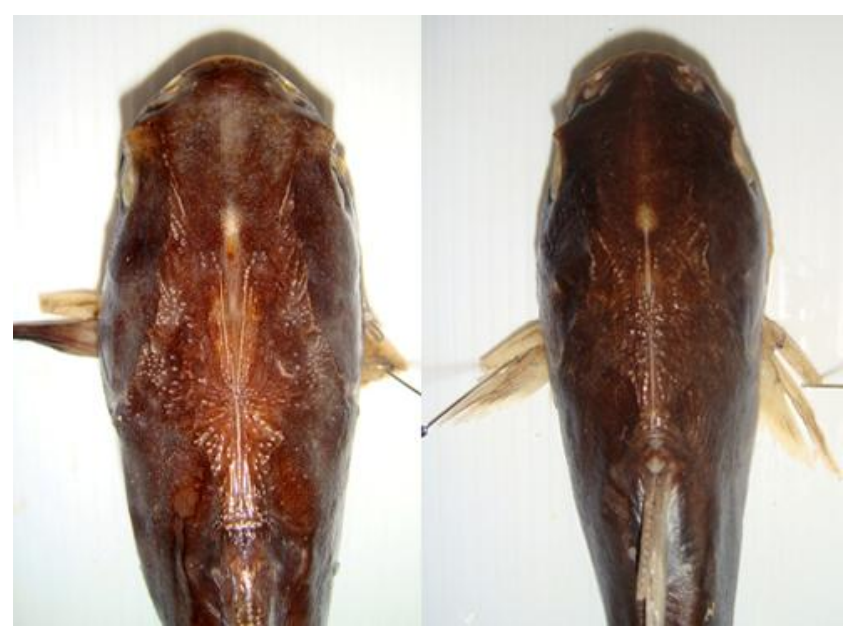

Figure 4. The head shield of Nemapteryx caelata (left) and Arius venosus (right) collected in this study

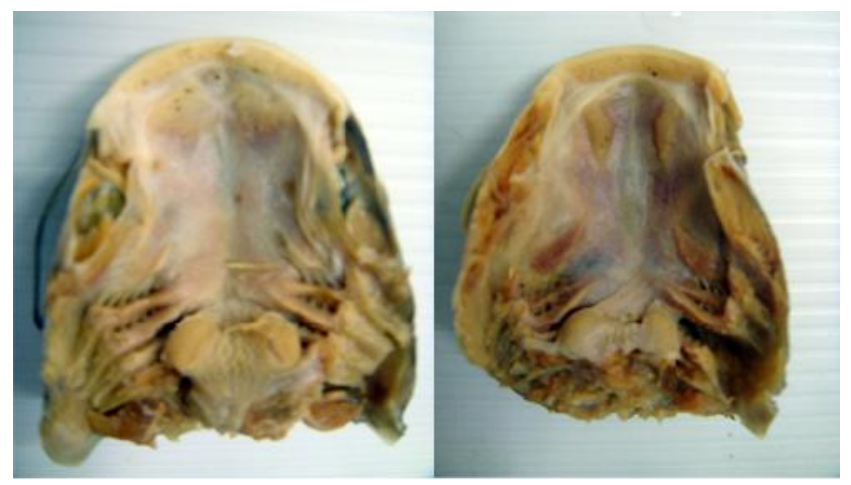

Figure 5. The palatal teeth of Nemapteryx caelata (left) and Arius venosus (right) collected in this study 


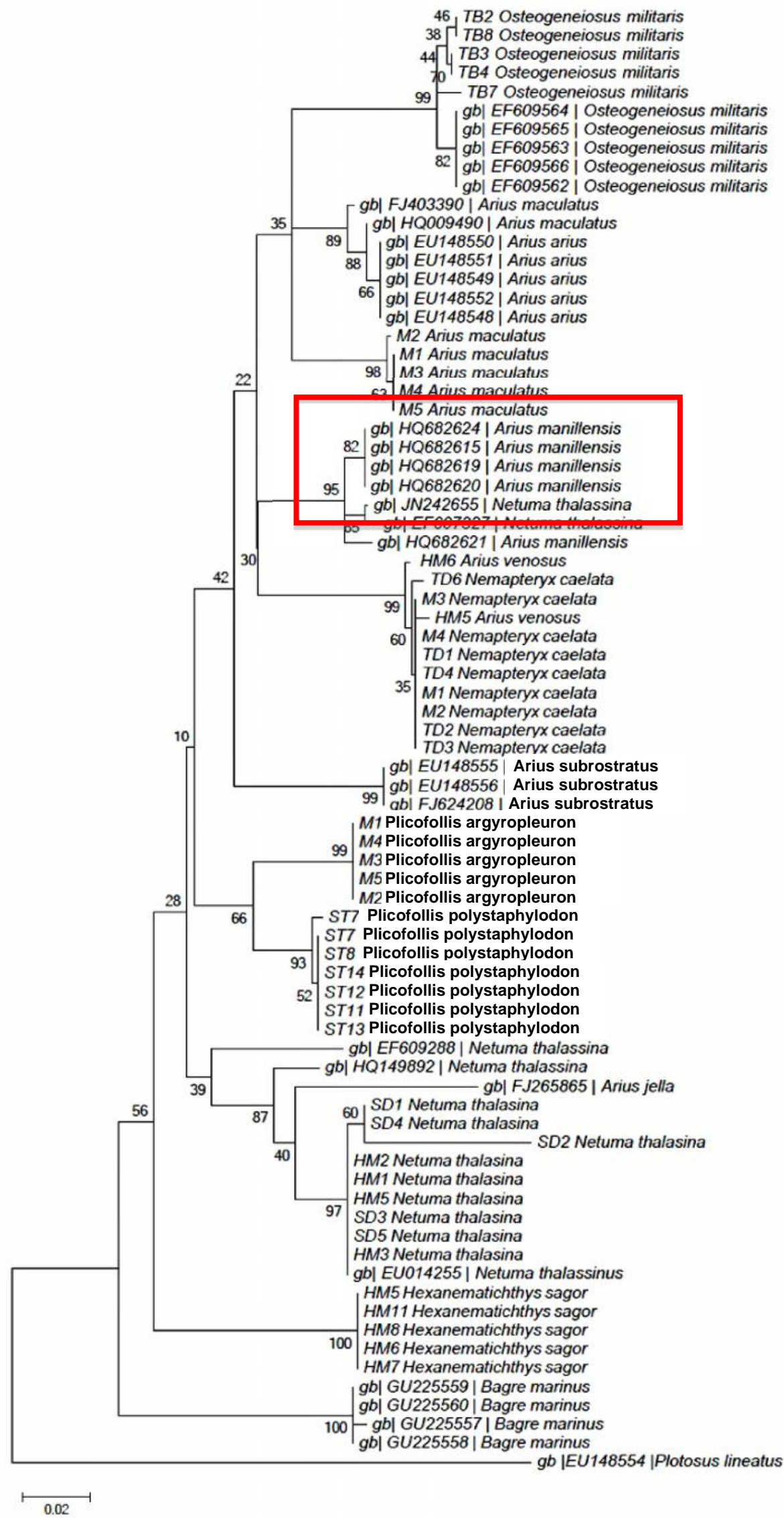

Figure 6. Phylogenetic tree among Ariidae species in Malaysia constructed under Maximum Likelihood (ML) algorithm including five sequences of $A$. manillensis obtained from GenBank 


\section{REFERENCES}

Adibah AB, Darlina MN. 2014. Is there a cryptic species of the golden snapper (Lutjanus johnii)? Genet Mol Res 13: 8094-104.

Barbuto M, Galimberti A, Ferri E, Labra M, Malandra R, Galli P, Casiraghi M. 2010. DNA barcoding reveals fraudulent substitutions in shark seafood products: The Italian case of "palombo" (Mustelusspp.). Food Res Int 43: 376-381.

Betancur RR, Acero PA. 2007. Systematics and biogeography of New World sea catfishes (Siluriformes: Ariidae) as inferred from mitochondrial, nuclear, and morphological evidence. Mol Phylogen Evol 45: 339-357.

Carpenter KE, Niem VH. 1999. The living marine resource of the Western Central Pacific. FAO species identification guide for fishery purpose 3: $1827-1879$

Cohen NJ, Deeds JR, Wong ES, Hanner R, Yancy HF, White KD, Thompson TM, Wahl M, Pham TD, Guichard FM, Huh I, Austin C, Dizikes G, Gerber SI. 2009. Public health response to puffer fish (tetrodotoxin) poisoning from mislabeled product. J Food Prot 72:810-817.

Department of Fisheries Malaysia. 2006. Annual fisheries statistic. http://www.dof.gov.my/index.php/pages/view/109.

Department of Fisheries Malaysia. 2007. Annual fisheries statistic. http://www.dof.gov.my/index.php/pages/view/108.

Felsenstein J. 2001. PHYLIP v3.6. Seattle, WA: Department of Genetics, Univ. of Washington.

Fischer W, Bianchi G. 1984. FAO Species Identification Sheets for Fishery Purposes. Western Indian Ocean Fishing Area 51. Rome: FAO.

Grewe P, Kruger CC, Aquadro CF, Bermingham E, Kincaid HL, May B. 1993. Mitochondrial DNA variation among lake trout strains stocked into Lake Ontario. Can J Fish Aquat Sci 50: 2397-2403.

Hall TA. 1999 .BioEdit: A user-friendly biological sequence alignment editor and analysis program for Windows 95/98/NT. Nucl Acids Symp Ser 41:95-98.

Hebert PDN, Stoeckle MY, Zemlak TS, Francis CM. 2004. Identification of birds through DNA barcodes. PLoS Biology 2: 1657-1663.

Hebert PDN, de Waard JR, Landry JF. 2010. DNA barcodes for 1/1000 of the animal kingdom. Biology Letters 6: 359-362.

Jennifer J, Dirk Z, Daniel P. 2010. Counting fish: a typology for fisheries catch data. J Integ Environ Sci 7: 135-144.
Kailola PJ. 2004. A phylogenetic exploration of the catfish family Ariidae. The Beagle (Rec. Mus. Art Galleries N. Terr.) 20: 87-166.

Kimura M. 1980. A simple method for estimating evolutionary rate of base substitutions through comparative studies of nucleotide sequences. J Mol Evol 16: 111-120.

Lowenstein J, Amato G, Kolokotronis S. 2009. The real maccoyii: identifying tuna sushi with DNA barcodes:

contrasting characteristic attributes and genetic distances. PLoS ONE 4: e7866.

Marceniuk AP, Menezes NA. 2007. Systematics of the family Ariidae (Ostariophysi, Siluriformes), with a redefinition of the genera. Zootaxa 1416: 1-126.

Miller DM, Jessel A, Mariani S. 2011. Seafood mislabeling: comparisons of two western European case studies assist in defining influencing factors, mechanisms and motives. Fish Fish. DOI: 10.1111/j.14672979. (2011)00426.

Rasmussen RS, Morrissey MT, Hebert PDN. 2009. DNA barcoding of commercially important salmon and trout species (Oncorhynchus and Salmo) from North America. J Agr Food Chem 57: 8379-8385.

Steinke D, Zemlak TS, Hebert PD. 2009. Barcoding nemo: DNA-based identifications for the ornamental fish trade. PLoS One 4: e6300.

Tamura K. Dudley J, Nei M, Kumar S. 2007. MEGA4: Molecular Evolutionary Genetics Analysis (MEGA) software version 4.0. Mol Biol Evol 10:1093/molbev/msm092.

Tamura K, Peterson D, Peterson N, Stecher G, et al. 2011. MEGA5: molecular evolutionary genetics analysis using

maximum likelihood, evolutionary distance, and maximum parsimony methods. Mol. Biol. Evol. 28: 2731-2739.

Thompson JD, Higgins DG, Gibson TJ. 1994. CLUSTAL W: improving the sensitivity of progressive multiple sequence alignment through sequence weighting, position-specific gap penalties, and weight matrix choice. Nucl Acids Res 22:4673-4680.

Ward RD, Zemlak TS, Innes BH, Last PR, et al. 2005. DNA barcoding Australia's fish species. Philos. Trans. R. Soc. Lond. B Biol. Sci. 360: 1847-185.

Ward RD, Hanner R and Hebert PD. 2009. The campaign to DNA barcode all fishes, FISH-BOL. J. Fish Biol. 74: 329-356.

Wongratana T, Bathia U. 1974. Ariidae. In: Fischer W, Whitehead PJP (eds.). FAO species identification sheets for fishery purposes. Eastern Indian Ocean (fishing area 57) and Western Central Pacific (fishing area 71). Vol. 1. FAO, Rome. 